\title{
APPLICABILITY EVALUATION OF Cupressus lusitanica FOR PULP PRODUCTION
}

\author{
Caio Cesar Faedo de Almeida ${ }^{1, \star}$, Polliana D'Angelo Rios ${ }^{2}$, \\ Alexsandro Bayestorff da Cunha ${ }^{3}$, Camilla Gabriela Melo Ampessan ${ }^{4}$, Alana Spanhol ${ }^{5}$
}

\begin{abstract}
This paper aimed to study Cupressus lusitanica wood tracheids biometrics along radial direction and chemical analysis in order to encourage the use of new forest species for pulp production in southern Brazil. Axial tracheids anatomical analysis was held in 3 positions, in the pith-periphery direction. Total length, total diameter and lumen diameter were analyzed, and wall thickness, flexibility coefficient, wall fraction, felting index and Runkel's ratio were calculated based on these variables. Chemical analysis determined total extractives, sodium hydroxide attack degree, ash, lignin and holocellulose content. For anatomical variables, a statistically significant increase in the pith-periphery direction was observed for total length $(\mathrm{L}=5,85 \mathrm{~mm})$, for total diameter $(\mathrm{D}=47,18 \mu \mathrm{m})$, lumen diameter $(\mathrm{d}=$ $32,92 \mu \mathrm{m})$ and wall thickness $(\mathrm{e}=14,26 \mu \mathrm{m})$ was observed stabilization from intermediate section. The species was characterized as with high rigidity tracheids (WF $=61,73 \%$ ), although being considered "good" for wood pulp production (RI $=0,93$ ). The chemical composition showed high lignin content $(\mathrm{L}=36,21 \%)$ and low holocellulose content $(\mathrm{H}=59,19 \%)$. Cupressus lusitanica wood showed appropriate anatomical characteristics to be part of the pulp industry raw material supply. However, chemical properties may compromise the species use due to high lignin content.
\end{abstract}

Keywords: Cypress, felting index, fiber lenght, Runkel index, tracheids.

\section{INTRODUCTION}

Brazil was the $5^{\text {th }}$ largest world pulp producer (softwood and hardwood) in 2000, surpassed by the United States, Canada, Japan and Finland (ABRAF 2013). However, in the last decade, industry investment and national economic development exerted great impact on pulp production (BRACELPA 2013). It provided an increase of $87,7 \%$ in pulp domestic production and $190,4 \%$ in exports. Brazil's market share in the international pulp market went from 9,6\% to significant $21 \%$ (ABRAF 2013).

According to IBÁ (2015), in 2014, Brazilian pulp production increase 8,8\% when compared to 2013. During that year 16,46 million pulp tons were produced, evidencing Brazil as the $4^{\text {th }}$ largest world Pulp producer, only suprassed by United States, China and Canada.

The expected pulp domestic industry growth will require large forest areas planting, in addition to cold-resistant species studies, as southern Brazil states planting will be of great importance for the

\footnotetext{
${ }^{1}$ Master in Forest Engineering, Department of Forestry, Universidade do Estado de Santa Catarina, Lages, Santa Catarina, Brazil. ${ }^{2}$ Associate Professor II, Department of Forestry, Universidade do Estado de Santa Catarina, Lages, Santa Catarina, Brazil, polliana.rios@udesc.br,

${ }^{3}$ Associate Professor IV, Department of Forestry, Universidade do Estado de Santa Catarina, Lages, Santa Catarina, Brazil, alexsandro.cunha@udesc.br,

${ }^{4}$ Master in Forestry, Department of Forestry, Universidade do Estado de Santa Catarina, Lages, Santa Catarina, Brazil, camillaampessan@hotmail.com

${ }^{5}$ Master in Forestry, Department of Forestry, Universidade do Estado de Santa Catarina, Lages, Santa Catarina, Brazil, alana spanhol@hotmail.com

"Corresponding author: caio-almeida@florestal.eng.br

Received: 28.05.2015 Accepted: 30.07.2016
} 
sector (Alves et al. 2011). Mostly because the majority of Brazilian companies producing pulp and/or paper are located in the South and Southeast regions of the country (IBÁ 2015).

The Brazil's southern region is very heterogenic, to the east, near the coast, there are important mountain chains formed by the Serra do Mar and Serra Geral mountains that constitute the highest elevations in southern Brazil. Heavy fogs frequently occur in these localities as well as snap freezes and frequent snowfalls, principally in the Serra Catarinense and Serra Gaúcha regions. Land elevation gradually diminishes westward, where the climate becomes warmer and drier (Higuchi et al. 2012).

Frost occurrence is very normal in the Brazil's southern region during fall and winter and produces severe damages to many Eucalyptus species (Soares et al. 2002). Thus, pine species use is essential. However, it is necessary to diversify the raw material through the study of alternative species to commonly used Pinus genus.

Among species with potential for southern Brazil soil and climatic conditions adaptation, Cupressus lusitanica (Okino et al. 2008) stands out. According to Shimizu et al. (1995), the species is suitable for plantation at elevations of $1500 \mathrm{~m}$, with mean annual rainfall between $1000 \mathrm{~mm}$ and $1600 \mathrm{~mm}$, and mean annual temperature of up to $17^{\circ} \mathrm{C}$.

This species does not have large plantation areas in Brazil, and areas are mostly directed for research or experiments. The species adapts well, with rapid growth and high annual increase, which ranges from 20 to $35 \mathrm{~m}^{3} /$ ha.year, with the species being also capable of surpassing Pinus elliottii growth (Foelkel and Zvinakevicius 1978, Pereira and Higa 2003).

Thus, if new species that stand out for good adaptation and rapid growth are available, it is necessary to assess their country's exploitation potential and quality.

Likewise, Punches (2004) described that there is a need to study wood characteristics, since they are directly related to specific application and, depending on the final use, these properties are critical factors and must be taken into account in selecting the most suitable materials for industrial use.

Clarke and Wessels (1995) stated that for the pulp and paper industry, the quality assessment process is not limited to the product analysis. In order to increase the process efficiency, all aspects that may influence the final product quality are analyzed, and a significant part lies in raw material improvement. However, there are still little available information about $C$. lusitanica wood pulp and paper properties, and little information touch on this species in the question of its features.

In wood pulping process studies, Gomide and Colodette (2007) referred to wood quality as the main parameter, since it is directly related to the wood anatomical and chemical structures. In the pulp and paper industry, the most popular species used as raw material for pulp production, has some contributing factors which include, excellent silvicultural characteristics for commercial planting and high yield rates. Besides wood quality, which is related to fiber dimensions as length and lumen diameter, wood specific gravity between $400-550 \mathrm{~kg} / \mathrm{m}^{3}$ and chemical compounds determination, highlighting cellulose and lignin (Punches 2004, Sansígolo and Ramos 2011).

Thus, this work had as objective the study of biometrics of tracheid along the radial direction and chemical analysis of the species of $C$. lusitanica in order to direct the use of the species for the production of cellulose and aiming at the determination of the ideal point for harvest. 


\section{MATERIAL AND METHODS}

The wood used to carry out the study came from a 19 years old Cupressus lusitanica MILL., experimental stand belonging to Florestal Gateados company, located in the municipality of Campo Belo do Sul, Santa Catarina state.

\section{Sampling}

$42 \mathrm{logs}$ with an average diameter ranging from 20 to $40 \mathrm{~cm}$ were obtained, and 5 trees out of them were selected according to COPANT 458 (1972) methodology, where the raw material used to carry out the chemical analysis was obtained from the first $\log$. For $C$. lusitanica wood tracheid analyzes, the used material was derived from an approximately $5 \mathrm{~cm}$ thick disc located at the 5 selected trees BHD $(1,30 \mathrm{~m})$ height.

Anatomical analysis of $C$. lusitanica wood aimed to obtain axial tracheids in the wood radial direction with 3 positions along the discs pith-periphery gradient. Samples were obtained in the pith, intermediate and periphery positions, which correspond to pith- periphery distance intervals of $0 \%$ (A1), 50\% (A2) and 100\% (A3), respectively, as shown in Figure 1.

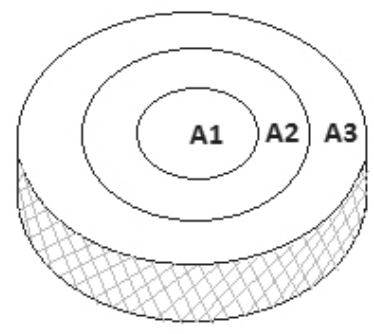

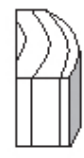

A1

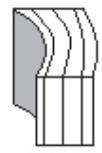

A2

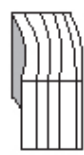

A3

Figure 1. Specimen withdrawal position scheme for tracheids biometrics variation study.

\section{Axial tracheids Analysis}

The C. lusitanica small wooden fillets were obtained 40 samples for maceration technique application, following the methodology described by Franklin (1945).

Macerate samples were measured through the following variables; total length $(\mathrm{L})$, total diameter (D) and lumen diameter (d) and wall thickness (e), in EUROMEX microscope, measured with the aid of lens with microns $(\mu \mathrm{m})$ graduated reticule. According to the variables, important pulp and paper production anatomical parameters were assessed, such as: flexibility coefficient (FC), wall fraction (WF), felting index (FI) and Runkel's index (RI).

\section{Samples chemical analysis}

Analyses were performed using $C$. lusitanica 40-60 mesh sawdust (dry basis) following TAPPI standards recommendations - Technical Association of Pulp and Paper Industry (TAPPI) and ABNTNBR, with these being described in Table 1. 
Table 1. Wood chemical analysis and standards list.

\begin{tabular}{|l|l|}
\hline Procedures & Standards \\
\hline Analysis Material Preparation & T264 - cm 07* \\
\hline Holocellulose Content & Through difference \\
\hline Lignin Content & T222 - om 02* \\
\hline Total Extractives Content & NBR 14660:2004** \\
\hline Inorganic Material Content (Ashes) & T211 - om 02* \\
\hline Sodium Hydroxide Solubility & NBR 7990:2010** \\
\hline \multicolumn{1}{|l}{$*$ Technical Association of Pulp and Paper Industry procedures **Brazilian Standards. }
\end{tabular}

\section{Statistical analysis}

Data were submitted to the Kolmogorov-Smirnov's test at 5\% probability. Studied material chemical variables means, standard deviation and coefficient of variation $(\mathrm{CV} \%)$ analyses were carried out when data normality was shown. As for tracheid analysis assessment, Tukey's test (TSD) at 5\% probability was applied.

\section{RESULTS AND DISCUSSION}

\section{Dimensional tracheids analysis}

Total length (L), total diameter (D), lumen diameter (d) and wall thickness (e) of wood anatomical characteristics results along radial direction are shown in Table 2.

Table 2. Cupressus lusitanica's pith-periphery direction tracheid dimensions.

\begin{tabular}{|c|c|c|c|c|c|}
\hline \multirow{4}{*}{ Section } & $\mathrm{L}(\mathrm{mm})$ & $\mathrm{D}(\mu \mathrm{m})$ & $\mathrm{d}(\mu \mathrm{m})$ & $\mathrm{e}(\mu \mathrm{m})$ \\
\hline \multirow{4}{*}{ Pith } & Mean & $4,79 \mathrm{c}$ & $45,49 \mathrm{~b}$ & $31,55 \mathrm{~b}$ & $13,94 \mathrm{~b}$ \\
\cline { 2 - 6 } & Minimum & 3,40 & 27,20 & 13,60 & 6,80 \\
\cline { 2 - 6 } & Maximum & 6,30 & 78,20 & 57,80 & 23,80 \\
\cline { 2 - 6 } & Standard Deviation & 0,62 & 0,78 & 0,76 & 0,31 \\
\hline \multirow{4}{*}{ Intermediate } & Mean & $5,98 \mathrm{~b}$ & $48,38 \mathrm{a}$ & $34,32 \mathrm{a}$ & $14,06 \mathrm{ab}$ \\
\cline { 2 - 6 } & Minimum & 4,39 & 27,20 & 13,60 & 6,80 \\
\cline { 2 - 6 } & Maximum & 8,69 & 81,60 & 68,00 & 30,60 \\
\cline { 2 - 6 } & Standard Deviation & 0,77 & 0,86 & 0,91 & 0,35 \\
\hline \multirow{4}{*}{ Periphery } & Mean & $6,85 \mathrm{a}$ & $47,67 \mathrm{a}$ & $32,87 \mathrm{ab}$ & $14,79 \mathrm{a}$ \\
\cline { 2 - 6 } & Minimum & 5,40 & 30,60 & 17,00 & 6,80 \\
\cline { 2 - 6 } & Maximum & 8,90 & 68,00 & 51,00 & 23,80 \\
\cline { 2 - 6 } & Standard Deviation & 0,82 & 0,67 & 0,63 & 0,30 \\
\hline
\end{tabular}

Means followed by the same minuscule letter in the column do not differ by Tukey's test at $95 \%$ probability. (L: tracheid length; D: tracheid total diameter; d: lumen diameter; e: wall thickness).

For the analyzed variables, a statistically significant increase was observed in the pith-periphery direction for tracheid length only, wall thickness has only statistical difference between pith and periphery sections. Total diameter has pith section lower than intermediate and periphery sections. For lumen diameter, tracheids in wood intermediate portion differ from pith section and is statistically equal as periphery region. 
The study material showed tracheid mean length of $5,85 \mathrm{~mm}$, the values were higher than obtained for 56 years old C. lusitanica (2,9 mm) (Pereira and Higa 2003), 22 years old Cryptomeria japonica $(2,21 \mathrm{~mm})$ (Pereira et al. 2003), 12 years old Pinus tecunumanii (4,56 mm) (Shimoyama and Wiecheteck 1993), P. caribaea $(4,08 \mathrm{~mm})$, P. patula $(3,85 \mathrm{~mm})$, . oocarpa $(4,00 \mathrm{~mm})$ ranging 28 to 35 year old (Anoop et al. 2014) and 18 years old $P$. taeda $(3,03 \mathrm{~mm}$ ) (Castelo et al. 2008). It was only similar to a 38 years old A. angustifolia tracheid length; $5,84 \mathrm{~mm}$, obtained by Mattos et al. (2006).

The 19 years old $C$. lusitanica, wall thickness had a mean value of $14,26 \mu \mathrm{m}$. This was a higher result than those observed within the same species; 5,90 $\mu \mathrm{m} 56$ year old (Pereira and Higa 2003) and 17 year old $C$. lusitanica $(4,1 \mu \mathrm{m}), C$. arizonica $(3,8 \mu \mathrm{m})$ C. sempervirens $(4,4 \mu \mathrm{m})$ (Santos et al. 2014). As well as other conifers such as C. japonica; 5,50 $\mu \mathrm{m}$ (Pereira et al. 2003), and A. angustifolia; 7,30 $\mu \mathrm{m}$ (Mattos et al. 2006), P. caribaea $(5,13 \mu \mathrm{m})$, P. patula $(4,98 \mu \mathrm{m})$, . P. oocarpa $(5,50 \mu \mathrm{m})$ up to 28 year old (Anoop et al. 2014).

Species that were closer to C. lusitanica were P. tecunumanii, with 10,00 $\mu \mathrm{m}$ (Shimoyama and Wiecheteck 1993), P. taeda, with $9,33 \mu \mathrm{m}$ (Castelo et al. 2008), and P. elliottii, with 8,80 $\mu \mathrm{m}$ (Barrichelo 1984).

Unlike previous variables, total diameter (D) and lumen diameter (d) showed constant values from the intermediate portion, with mean values of 47,18 and $32,92 \mu \mathrm{m}$, respectively. The 19 years old $C$. lusitanica showed values higher than $C$. lusitanica $(\mathrm{D}=34,3 \mu \mathrm{m}, \mathrm{d}=22,4 \mu \mathrm{m})$ (Pereira and Higa 2003), C. lusitanica $(\mathrm{D}=22,5 \mu \mathrm{m}, \mathrm{d}=19,5 \mu \mathrm{m})$, C. arizonica $(\mathrm{D}=20,2 \mu \mathrm{m}, \mathrm{d}=17,6 \mu \mathrm{m})$, C. sempervirens $(\mathrm{D}=23,2 \mu \mathrm{m}, \mathrm{d}=19,8 \mu \mathrm{m})($ Santos et al. 2014) and C. japonica $(\mathrm{D}=30,1 \mu \mathrm{m}, \mathrm{d}=19,2 \mu \mathrm{m})$ (Pereira et al. 2003) for both variables.

However, values were lower than those observed in P. tecunumanii ( $\mathrm{D}=54,80 \mu \mathrm{m}$ and $\mathrm{d}=34,90$ $\mu \mathrm{m})$ (Shimoyama and Wiecheteck 1993), P. caribaea $(\mathrm{D}=53,49 \mu \mathrm{m}$ and $\mathrm{d}=43,23 \mu \mathrm{m})$, P. patula $(\mathrm{D}$ $=48,52 \mu \mathrm{m}$ and $\mathrm{d}=34,73 \mu \mathrm{m}), P$. oocarpa $(\mathrm{D}=49,53 \mu \mathrm{m}$ and $\mathrm{d}=39,55 \mu \mathrm{m})$ (Anoop et al. 2014), $P$. taeda $(\mathrm{D}=53,76 \mu \mathrm{m}$ and $\mathrm{d}=35,11 \mu \mathrm{m})($ Castelo et al. 2008), P. elliottii $(\mathrm{D}=45,80 \mu \mathrm{m} \mathrm{d}=28,20 \mu \mathrm{m})$ (Barrichelo 1984) and A. angustifolia $(\mathrm{D}=54,95 \mu \mathrm{m}$ and $47,65 \mu \mathrm{m})$ (Mattos et al. 2006).

Thus, due to fiber length and wall thickness high values and reduced total diameter and lumen diameter values, higher paper strength and higher pulp yield may be expected. However, very thick fibers tend to keep their original form, what weaken interfiber bonding, decreasing strength and burst resistance, although it means an increase in tear resistance (Shimoyama and Wiecheteck 1993).

In addition to wood characteristics, anatomical relation indexes are essential for the selection of most suitable species to certain products and uses. Pulp and paper production influential parameters of C. lusitanica wood is described in Table 3. 
Table 3. Pulp and paper production dimensional relations.

\begin{tabular}{|c|c|c|c|c|c|}
\hline \multicolumn{2}{|l|}{ Section } & FC (\%) & WF (\%) & FI & RI \\
\hline \multirow{4}{*}{ Pith } & Mean & $68,73 \mathrm{a}$ & $62,54 \mathrm{a}$ & $115,50 \mathrm{c}$ & $0,95 \mathrm{a}$ \\
\cline { 2 - 6 } & Minimum & 40,00 & 26,67 & 71,26 & 0,31 \\
\cline { 2 - 6 } & Maximum & 86,67 & 120,00 & 182,61 & 3,00 \\
\cline { 2 - 6 } & Standard Deviation & 7,80 & 15,61 & 1,93 & 0,37 \\
\hline \multirow{4}{*}{ Intermediate } & Mean & $70,12 \mathrm{a}$ & $59,74 \mathrm{a}$ & $124,10 \mathrm{~b}$ & $0,90 \mathrm{a}$ \\
\cline { 2 - 6 } & Minimum & 45,45 & 20,00 & 85,14 & 0,22 \\
\cline { 2 - 6 } & Maximum & 90,00 & 109,09 & 184,46 & 2,40 \\
\cline { 2 - 6 } & Standard Deviation & 8,48 & 16,95 & 1,96 & 0,38 \\
\hline \multirow{5}{*}{ Periphery } & Mean & $68,54 \mathrm{a}$ & $62,92 \mathrm{a}$ & $132,73 \mathrm{a}$ & $0,95 \mathrm{a}$ \\
\cline { 2 - 6 } & Minimum & 46,15 & 33,33 & 88,94 & 0,40 \\
\cline { 2 - 6 } & Maximum & 83,33 & 107,69 & 181,86 & 2,33 \\
\cline { 2 - 6 } & Standard Deviation & 6,96 & 13,92 & 2,16 & 0,32 \\
\hline
\end{tabular}

Means followed by the same minuscule letter on the columns do not differ by Tukey's test at 95\% probability (FC: flexibility coefficient; WF: wall fraction; FI: felting index; RI: Runkel's index).

C. lusitanica wood tracheids relation indexes variation in pith-periphery direction showed statistical significance for the felting index only.

Among these indexes, the flexibility coefficient relates lumen diameter and fiber length, and the higher its value, the more flexible will be the fiber, with more connections being likely to occur between them, what would increase tension and burst resistance (Shimoyama and Wiecheteck 1993). Thus, C. lusitanica wood has a mean FC value $(69,13 \%)$, being higher than values observed for $P$. taeda (66,71\%) (Castelo et al. 2008) and P. tecunumanii (64,00\%) (Shimoyama and Wiecheteck 1993).

Wall fraction is a relation that must be assessed in the reverse of flexibility coefficient. Values below $40 \%$ are expected, so that fibers are not too rigid (Nisgoski et al. 2011). However, the material under study had a mean value of $61,73 \%$; which is much higher than P. tecunumanii, $36 \%$ (Shimoyama and Wiecheteck 1993) and P. taeda 33,29\% (Castelo et al. 2008), meaning that $C$. lusitanica fibers are extremely rigid, inflexible and with interconnection difficulties (Rocha et al. 2004).

Regarding, felting index tracheids showed higher quality along the pith-periphery gradient, so that the wood next to the periphery region has higher resistance to tearing and rapture than wood pith and intermediate sections. In order to produce good quality papers, higher than 50 felting index values are necessary (Nisgoski et al. 2011), what is reached on C lusitanica wood.

The higher felting index mean obtained in C. lusitanica was of 132,75 on periphery section, Nisgoski et al. (2011) describes that conifers can reach values higher than 60 , as obtained by Castelo et al. (2008) in P. taeda, 61,85 and Shimoyama and Wiecheteck (1993) in P. tecunumanii, 83.

Runkel's index showed no variation along positions, with a mean value of 0,93 . The Runkel ratio is the ratio of fiber cell wall thickness to its lumen that determines the suitability of a fibrous material for pulp and paper production. If a wood species has a high Runkel ratio, its fiber will be stiff and less flexible and poor bonding ability. High Runkel ratio fibers produce bulkier paper than fibers with low Runkel ratio (Kiaei et al. 2014).

Fiber quality can be considered as "good", Rocha et al. (2004) mentions that fiber quality with up to 0,25 index is considered excellent for paper; from 0,25 to 0,50 is very good; from 0,50 to 1 is good; from 1 to 2 is regular, and above 2 may not be used for paper. 
The value observed was higher than described by Anoop et al. (2014) wich maximum values were below 0,60 for P. caribaea, P. patula and P. oocarpa on the same sections evaluated.

Even with high wall thickness and low flexibility coefficient, $C$. lusitanica wood showed suitable characteristics to supply the pulp and paper industry, with better RI values than some commonly used species in industry, such as $P$. taeda, with 0,52 (Castelo et al. 2008), P. tecunumanii, with 0,57 (Shimoyama and Wiecheteck 1993), and Eucalyptus grandis, 0,60 (Rocha et al. 2004).

However, contrary to Foelkel and Zvinakevicius (1975) and Pereira and Higa (2003), C. lusitanica wood has suitable anatomical characteristics for kraft pulp production, especially higher tear resistance compared to Pinus sp. species, which are commonly grown for pulp and paper production in southern Brazil.

The results also demonstrate a stabilization in the morphological parameters from the intermediate section and suggest the anticipation in the harvest of the afforestation, reducing the rotation duration.

\section{Chemical Analysis}

Results shown in Figure 2 are related to $C$. lusitanica wood chemical composition values through the following variables: total extractives, ash content, lignin content and holocellulose content.

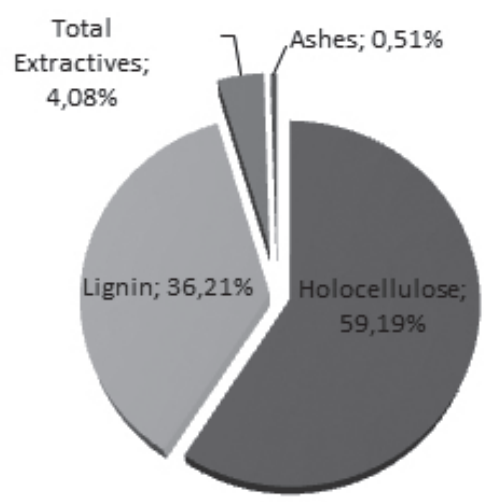

Figure 2. Cupressus lusitanica wood constituent levels.

Total extractives content showed values ranging from 3,56 to 4,73\%; and the maximum range was of $1,17 \%$. Klock et al. (2005) reported that this content usually ranges from 5 to $8 \%$ in coniferous woods.

Likewise, Pereira and Higa (2003) found 7,3\% total extractives in 56 years old C. lusitanica plantations, while Okino et al. (2010) found a mean value of $4,1 \%$ for total extractives, a very close value to the one obtained in this study. In a study with $C$. lusitanica, C. arizonica and C. sempervirens, Santos et al. (2014) observed total extractives values of 3,87; 2,46 and 3,34\% respectively.

When compared to other conifers, $C$. lusitanica total extractive levels are higher than those obtained in A. angustifolia 3,8\% (Mattos et al. 2006), and lower than C. japonica 4,9\% and P. elliottii, 4,98\% (Pereira et al. 2003), P. pinaster (5,05\%) and P. sylvestris (4,47\%) obtained by Santos et al. (2014).

Wood extractives influence is of fundamental importance for species establishment, especially for forest-based industry unusual species, with main emphasis in the pulp and paper industry production processes. 
Thus, extractives presence negatively affects productive pulping aspects, besides also causing increased reagents consumption, delignification reaction inhibition, equipment corrosion, pulp quality reduction and cooking liquor recovery hindering (Fengel and Wegener 1989, MIMMS 1993, IPT 1988, Sarto 2010). Therefore, species used for pulp and paper production need to have low extractive levels in its constitution, and C. lusitanica has acceptable extractive levels compared to already used Pinus spp. species.

In sodium hydroxide solubility analysis, mean values were of $18,82 \%$ higher values than those obtained by Brand and Muniz (2012) in P. taeda $(14,24 \%)$ and E. dunnii $(16,49 \%)$ biomass studies. However, results were lower than those obtained by Trugilho et al. (2005) using Eucalyptus clones, in which $21,69 \%$ values were shown for sodium hydroxide extractives, what states that $C$. lusitanica wood has lower low molecular weight carbohydrates removal susceptibility (hemicellulose and degraded cellulose) than some Eucalyptus clones used for pulp production.

Inorganic material proportion in this study was shown through ash content, which had a mean of $0,51 \%$ what is close to commonly found values for conifers. According to Aló et al. (2011), Pinus sp. wood ash content is of $0,62 \%$ while Souza et al. (2012) obtained $0,45 \%$ content for P. taeda.

Lignin results of $C$. lusitanica had mean values of $36,21 \%$ which was higher when compared to lignin contents shown to the same specie and similar age by Okino et al. (2010) 33,5\% and Santos et al. (2014) 34,69\%. It also corroborate with Foelkel and Zvinakevicius (1975) and Pereira and Higa (2003), who observed lignin values of $33,53 \%$ and $29,9 \%$ respectively.

The lignin content of $C$. lusitanica wood showed higher values than those observed for $C$. sempervirens, 33,50\% (Santos et al. 2014), P. elliottii, 27,23\% (Pereira and Higa 2003), P. caribaea (29,54\%), P. patula (26,20\%), P. oocarpa (23,80) (Anoop et al. 2014), P. pinaster (29,12\%), P. sylvestris (28,48\%) (Santos et al. 2014), C. japonica 32,7\% (Pereira et al. 2003), A. angustifolia 27,8\% (Mattos et al. 2006), Eucalyptus sp., 27,5\% obtained by Gomide et al. (2005) and six E. globulus genotypes that vary up to $23,8 \%$ to $28 \%$ (Aguayo et al. 2015). The high lignin proportion in C. lusitanica wood affects cellulose-pulping process, where high percentages influence paper yield, brightness and bleachability (Fengel and Wegener 1989, MIMMS 1993, Dueñas 1997).

Holocellulose is the constituent with the highest wood proportion in C. lusitanica, totaling $59,19 \%$. However, the holocellulose content obtained was lower than what is expected for the species, and also low when compared to other conifer species. Okino et al. (2010) reported that, for the same species and with similar age 71,8\% holocellulose values were observed, corroborating with Foelkel and Zvinakevicius (1975), who obtained 71,6\% holocellulose and Pereira and Higa (2003), using 56 years old C. lusitanica wood obtained $62,6 \%$ holocellulose.

Comparative to other species, like P. elliottii, 67,78\% (Pereira and Higa 2003), C. japonica 65,6\% (Pereira et al. 2003), and A. angustifolia, 68,4\% (Mattos et al. 2006) holocellulose values were lower. In the present study, holocellulose value was superior only to P. caribaea $(33,54 \%)$, P. patula $(40,32 \%)$ and P. oocarpa (47,55\%) obtained by Anoop et al. (2014). 


\section{CONCLUSIONS}

It was concluded that $C$. lusitanica wood has adequate anatomical characteristics to be part of the pulp and paper industry raw material, such high tracheid length, high felting index and good Runkel's index. The values stabilization from the intermediate section for the majority of the features analyzed can suggest a harvest anticipation, which reduces the crop cycle and increases the economic gain.

However, chemical properties, especially the high lignin content and low holocellulose content, compromised the process yield and also increase the production cost of $C$. lusitanica wood in bleached paper. Thus, the species is more suitable for packaging and industrial bags production.

\section{ACKNOWLEDGEMENTS}

The authors thank FAPESC for granting the scholarship and for the financial support. The authors also express their thanks to the Gateados Florestal company for the raw material used in this study donation.

\section{REFERENCES}

Aguayo, M.G.; Ruiz, J.; Norambuena, M.; Mendonça, R. . 2015. Structural features of dioxane lignin from Eucalyptus globulus and their relationship with the pulp yield of contrasting genotypes. Maderas. Ciencia y Tecnología 17(3):625-636.

Aló, L.L.; Yamaji, F. M.; Konishi, P.A.; Junior, C. R. S. 2011. Caracterização de blendas em diferentes porcentagens de Pinus sp. e pó de lixa para a produção de biocombustível sólido. Anais do $6^{\circ}$ Congresso Internacional de Bioenergia, Curitiba.

Alves, I.C.N.; Gomide J.L.; Colodette, J.L.; Silva, H.D. 2011. Caracterização tecnológica da madeira de Eucalyptus benthamii para produção de celulose Kraft. Ciência Florestal 21(1):167-174.

Anoop, E.V.; Ajayghosh, V.; Nijil, J.M.; Jijeesh, C.M. 2014. Evaluation of pulp wood quality of selected tropical pines raised in the high ranges of Idukki District, Kerala. Journal of Tropical Agriculture 52(1):59-66.

Associação Brasileira de Celulose e Papel. BRACELPA. 2013. O setor brasileiro de celulose e papel. Associação Brasileira de Celulose e Papel. São Paulo.

Associação Brasileira de Produtores de Florestas Plantadas. ABRAF. 2013. Anuário estatístico da ABRAF 2013, Ano base 2012, Brasília.

Associação Brasileira de Normas Técnicas. ABNT 2004. NBR 14660. Madeira - Amostragem e preparação para análise, Brasil.

Associação Brasileira de Normas Técnicas. ABNT 2010. NBR 7990 Madeira - Determinação do material solúvel em hidróxido de sódio a 1\%, Brasil.

Barrichelo, L.E.G. 1984. Caracterização de madeiras de Pinus spp. Boletim Informativo IPEF, Piracicaba 3(14):100-112. 
Brand, M.A.; Muñiz, G. I. B. 2012. Influência da época de colheita e da estocagem na composição química da biomassa florestal. Floresta e Ambiente 19: 66-78.

Castelo, P.A.R.; Matos, J.L.M.; Dedecek, R.A.; Lavorant, O.J. 2008. Influência de diferentes sítios de crescimento sobre a qualidade da madeira de Pinus taeda. Floresta 38(3):495-506.

Clarke, C. R. E.; Wessels, A. M. 1995. Variation and measurements of pulp properties in Eucalyptus. In: IUFRO World Congress.

COPANT. 1972. Comission Panamericana de Normas Tecnicas. Madeiras. Selección y colección de muestras, COPANT 458-1972.

Dueñas, R.S. 1997. Obtención de pulpas y propriedades de las fibras para papel. Guadalajara. Universidad de Guadalajara. ed.1,293p.

Fengel, D.; Wegener, G. 1989. Wood. Chemistry: Ultrastructure: Reactions. Berlin. Walter de Gruyter.

Foelkel, C.E.B.; Barrichelo, L.E.G. 1975. Relações entre características da madeira e propriedades da celulose e papel. O Papel 36(9):49-53.

Foelkel, C.E.B.; Zvinakevicius, C. 1978. Coníferas exóticas aptas para produção de celulose Kraft: 2-Cupressus lusitanica. Belo Oriente, 18p.

Franklin, G.L. 1945. Preparation of thin sections of synthetic resins and wood-resin composites, and a new macerating method for wood. Nature, 155(3924):51-51.

Gomide, J.L.; Colodette, J.L. 2007. Qualidade da madeira. In: BOREM, A. (Ed.) Biotecnologia florestal. Viçosa, MG: Universidade Federal de Viçosa, p.25-54.

Gomide, L.J.; Colodette, L.J.; Olveira, R.C.; Silva, C.M. 2005. Caracterização tecnológica, para produção de celulose, da nova geração de clones de Eucalyptus do Brasil. Árvore 29(1):129-137.

Higuchi, P.; Silva, A.C.; Ferreira, T.S.; Souza, S.T.; Gomes, J.P.; Silva, K.M.; Santos, K. F. 2012. Floristic composition and phytogeography of the tree component of Araucaria Forest fragments in southern Brazil. Brazilian Journal of Botany 35(2):145-157.

IBÁ. 2015. Indústria Brasileira de Árvores. Indústria brasileira de árvores. Brasília.

IPT. 1988. Celulose e papel. Instituto de Pesquisas Tecnológicas de São Paulo - Vol I.

Klock, U.; de Muñiz, G. I. B.; Hernandez, J. A.; de Andrade, A. S. 2005. Química da madeira, $3^{\circ}$ ed. Curitiba.

Kiaei, M.; Tajik, M.; Vaysi, R. 2014. Chemical and biometrical properties of plum wood and its application in pulp and paper production. Maderas. Ciencia y Tecnología 16(3):313-322.

Mattos, P.P.; Bortoli, C.; Marchesan, R.; Rosot, M. C. 2006. Caracterização Física, Química e Anatômica da Madeira de Araucaria angustifolia (Bert.) O. Kuntze. Comunicado Técnico, Colombo, n. 160.

MIMMS. 1993. Kraft pulping, a compilation of notes. Atlanta. TAPPI PRESS. ed.2, 181p.

Nisgoski, S.; Trianoski, R.; Muniz, G. I. B.; Matos, J. L. M; Batista, F. R. R. 2011. Anatomia da madeira de Toona ciliata Características das fibras para produção de papel. Floresta 41(4):717-728. 
Okino, E.Y.; Teixeira, D.E.; de Souza, M.R.; Santana, M.A.E.; de Sousa, M. E. 2008. Propriedades de chapas OSB de Eucalyptus grandis e de Cupressus glauca. Scientia Forestalis 36(78):123-131.

Okino, E.Y.A.; Santana, M. A. E.; Alves, M.V.; Melo, J.E.; Coradin, V.T.R.; Souza, M.R.; Teixeira, D.E.; Sousa, M.E. 2010. Technological Characterization of Cupressus spp. Wood. Floresta e Ambiente 17(1):1-11.

Pereira, J.C.D.; Higa, R.C.V. 2003. Propriedades da Madeira de Cupressus lusitanica Mill. Comunicado técnico. Paraná, $n^{\circ} 107$.

Pereira, J.C. D.; Higa, R.C. V; Shimizu, J.Y. 2003. Propriedades da madeira do Cedrinho Japonês. Comunicado Técnico, Colombo, n. 88.

Punches, J. 2004. Tree growth, forest management, and their implications for wood quality. Oregon State University. $8 \mathrm{p}$.

Rocha, F.T.; Florsheim, S.M. B.; do Couto, H. T. Z. 2004. Variação das dimensões dos elementos anatômicos da madeira de árvores de Eucalyptus grandis Hill ex Maiden aos sete anos. Rev Inst Flor $16(1): 43-55$

Sansígolo, C.A.; da Ramos, E.S 2011. Quality of wood and pulp from a clone of Eucalyptus grandis planted at three locations. Cerne 17(1):47-60.

Santos, A. J.A.; Anjos, O.; Morais, M.C.; Diogo, G.; Simões, R.; Pereira, H. 2014. Characterization of Cypress wood for Kraft Pulp production. Bioresources 9(3):4764-4774.

Sarto, C.; Sansigolo, C.A. 2010. Cinética da remoção dos extrativos da madeira de Eucalyptus grandis durante polpação Kraft. Maringá 32(3):227-235.

Shimizu, J.Y.; Pinto Júnior, J.E.; Ribaski, G. 1995. Cipreste para madeira: alto incremento volumétrico com material genético apropriado. Boletim de Pesquisa Florestal 30/31:3-17.

Shimoyama, V.R.S.; Wiecheteck, M.S.S. 1993. Características da madeira e da pasta termomecânica Pinus patula var. tecunumanii para produção de papel imprensa; Série Técnica IPEF 9(27):.63-80.

Soares, R. V.; Batista, A. C.; Souza, L. J. B. 2002. Fuel loading in Eucalyptus dunnii and Pinus taeda plantations in southern Brazil. In: IV International Conference on Forest Fire Research, 2002, Luso/Coimbra. Forest Fire Research \& Wildland Fire Safety. Rotterdam: Millpress Science Publishers, v. 1.

Souza, M.M.; Silva, D.A.; Rochadelli, R.; Santos, R. C. 2012. Estimativa de poder calorífico e caracterização para uso energético de resíduos da colheita e do processamento de Pinus taeda. Floresta 42(2):325-334.

Technical Association of Pulp and Paper Industry. TAPPI. 2002. Acid-insoluble lignin in wood and pulp. T 222 om- $02.5 \mathrm{p}$.

Technical Association of Pulp and Paper Industry. TAPPI. 2002. Ash in wood, pulp, paper and paperboard: combustion at $525^{\circ} \mathrm{C}$. T $211 \mathrm{om}-02.5 \mathrm{p}$.

Technical Association of Pulp and Paper Industry. TAPPI. 2007. Preparation of wood for chemical analysis, Test Method. T $264 \mathrm{~cm}-07$. 
Trugilho, P.F.; Bianchi, M. L.; Gomide, J. L.; Lima, J. T.; Mendes, L. M.; Mori, F. A.; Gomes, D.F.F. 2005. Clones de Eucalyptus versus a produção de polpa celulósica. Ciência Florestal 15(2):145155 . 